\title{
EFFECT OF PROGRESSIVE MUSCLE GYMNASTIC ON PHYSIOLOGICAL RESPONSE IN THE ELDERLY AT ALAK COMMUNITY HEALTH CENTER, KUPANG, EAST NUSA TENGGARA
}

\author{
Desak MPP Dewi, Jacob Ratu, Luh Putu Ruliati
}

Masters Program of Public Health, Universitas Nusa Cendana

\begin{abstract}
Background: The elderly are at a higher risk for degenerative diseases such as hypertension, diabetes, and dementia. This chronic condition leads to increased medical expense. Progressive muscle gymnastic is one of the non-pharmacological efforts to suppress the age-related disease. The importance of physical activity and regular exercise has been emphasized. This study aimed to examine the effect of progressive muscle gymnastic on physiological response in the elderly at Alak Community Health Center, Kupang, East Nusa Tenggara.

Subjects and Method: This was a quasi experiment with one group pretest-postest design. This study was conducted at Nunhila auxiliary health center of Community Health Center Alak, Kupang, East Nusa Tenggara. A sample of 20 elderly was selected for this study. The dependent variable was physiological response. The independent variable was progressive muscle gymnastic. The data of physiological response was obtained by several examinations. The data analyzed by t-test.

Results: Physiological response increased after intervention and it was statistically significant.

Conclusion: Physiological response increases with progressive muscle gymnastic and it is statistically significant.

Keywords: physiological response, elderly, progressive muscle gymnastics

Correspondence:

Desak Made P.P Dewi, Masters Program in Public Health, Universitas Nusa Cendana, Kupang 85001, East Nusa Tenggara. Email: desakmadeppd@gmail.com. Mobile: o81246616869 .
\end{abstract}

The $6^{\text {th }}$ International Conference on Public Health

Best Western Premier Hotel, Solo, Indonesia, October 23-24, $2019 \mid 358$

https://doi.org/10.26911/the6thicph.05.23 